\title{
Anti-HIV2 Enzyme Immunoassay
}

National Cancer Institute

\section{Source}

National Cancer Institute. Anti-HIV2 Enzyme Immunoassay. NCI Thesaurus. Code C95526.

An enzyme immunoassay for the qualitative detection of antibodies to human immunodeficiency viruses in human serum or plasma. 